\title{
Plasma cholinesterase activity in children with infective endocarditis
}

\author{
LJ Popovic ${ }^{*}$, S Alavuk, T Kovacevic \\ From 23rd World Congress of the World Society of Cardio-Thoracic Surgeons \\ Split, Croatia. 12-15 September 2013
}

\section{Background}

Although pre-existing heart disease in children is the most frequent predisposing factor for infective endocarditis (IE), we reporte 6 children of IE with no apparent pre-existing cardiac disease.

\section{Methods}

Our study included six patients with acquired infection from central catheter; the microbial pathogens were Streptococcus viridans $(\mathrm{n}=3)$ and Staphyloccocus aureus $(\mathrm{n}=3)$. The diagnosis of IE was based on positive blood culture ( 2 positive cultures of blood samples drawn $>12$ hours), evidence of endocardial involvement (positive $\mathrm{ECHO}$ ), measuring raised erythrocyte sedimentation rate and plasma cholinesterase (PChE) activity. We measured PChE activity $\left(\mu \mathrm{mol} \mathrm{min}{ }^{-1} \mathrm{ml}^{-1}\right)$ in children with IE (group $\mathrm{A}, \mathrm{n}=6$ ) and in IE-free children (group B, $\mathrm{n}=10$ ). For determination of PChE activity vein blood samples were collected and stored at $-20^{\circ} \mathrm{C}$ until analyzed. PChE activity was determined by the spectrophotometric method of Ellman using butyryltiocholine as the substract (Sigma Chemical Co., St.Luis, Mo, USA). Statistical analysis was made by Student's t-test.

\section{Results}

In group A of examined children with IE we measured decreased PChE activity $(1.89 \pm 0,24)$ relation to patients of control group B $(3,97 \pm 0,20)$.

\section{Conclusion}

Our study indicates that PChE activity can be also an important parameter for the diagnosis of IE.

* Correspondence: ljiljana.popovic1@gmail.com

Department of Anesthesiology, Reanimatology and Intensive Care, Children's Hospital Zagreb, Zagreb, Croatia
Published: 11 September 2013

doi:10.1186/1749-8090-8-S1-P177

Cite this article as: Popovic et al.: Plasma cholinesterase activity in children with infective endocarditis. Journal of Cardiothoracic Surgery 2013 8(Suppl 1):P177
Submit your next manuscript to BioMed Central and take full advantage of:

- Convenient online submission

- Thorough peer review

- No space constraints or color figure charges

- Immediate publication on acceptance

- Inclusion in PubMed, CAS, Scopus and Google Scholar

- Research which is freely available for redistribution
C Biomed Central

\section{Biomed Central}

